National Marine

Fisheries Service

Fishery Bulletin

Spencer F. Baird

NOAA

$\approx$ established in 1881

First U S Commissioner of Fisheries and founder of Fishery Bulletin

\begin{abstract}
The role of deepwater corals and sponges in the life history of fish species is generally unknown for the larval stage. In 2017, we deployed an autonomous plankton pump into deepwater coral habitat (depths: $>50 \mathrm{~m}$ ) to examine which species were present and captured a single rockfish larva. Using genetic methods, we identified the larva as a northern rockfish (Sebastes polyspinis). The unique capture of a freeswimming larva with a plankton pump in this study is the first in situ record of the use of deepwater coral habitat by rockfish larvae. Subsequent reexamination of coral specimens captured in bottom-trawl surveys that had been conducted in the Gulf of Alaska yielded an additional 10 northern rockfish larvae and a single harlequin rockfish (S. variegatus) larva lodged in the polyps of 2 species of deepwater coral. The results of this study improve our knowledge of the early life history of rockfish species, a taxonomic group that has limited lifetime dispersal indicated by a high degree of population structure. The capture and identification of the larva also indicate a potential mechanism for larval retention in the area of their extrusion and highlight the further importance of deepwater coral habitat as essential habitat for rockfish species.
\end{abstract}

Manuscript submitted 25 August 2021. Manuscript accepted 18 February 2022. Fish. Bull. 120:74-78 (2022).

Online publication date: 3 March 2022. doi: 10.7755/FB.120.1.7

The views and opinions expressed or implied in this article are those of the author (or authors) and do not necessarily reflect the position of the National Marine Fisheries Service, NOAA.

\title{
First observation of the use of coral habitat by larval northern rockfish (Sebastes polyspinis) in the western Gulf of Alaska
}

\author{
Rachel E. Wilborn ${ }^{1}$ \\ Ingrid Spies ${ }^{2}$ \\ Pamela Goddard ${ }^{1}$ \\ Christopher N. Rooper (contact author) ${ }^{3}$ \\ James W. Orr ${ }^{2}$
}

Email address for contact author: chris.rooper@dfo-mpo.gc.ca

${ }^{1}$ Lynker Technologies LLC for Alaska Fisheries Science Center National Marine Fisheries Service, NOAA 7600 Sand Point Way NE

Seattle, Washington 98115

\author{
${ }^{3}$ Pacific Biological Station \\ Fisheries and Oceans Canada \\ 3190 Hammond Bay Road \\ Nanaimo, British Columbia V9T 6N7, \\ Canada
}

${ }^{2}$ Alaska Fisheries Science Center National Marine Fisheries Service, NOAA 7600 Sand Point Way NE Seattle, Washington 98115

Deepwater coral and sponge habitats have been reported to support a higher diversity and abundance of many marine fish and invertebrate species than other non-structured habitats (Buhl-Mortensen and Mortensen, 2004; Watling et al., 2011). In the Northeast Pacific Ocean, rockfishes (Sebastes spp.) are linked to deepwater (depths: $>50 \mathrm{~m}$ ) corals and sponges because of their preference for structured habitats (Rooper et al., 2007). These studies were conducted almost exclusively on the juvenile and adult stages of the life history of rockfishes and other species, and the role of deep-sea corals and sponges in the larval stage of rockfishes is unknown. Understanding whether rockfish in early life stages utilize deep-sea coral and sponge habitats as settlement or nursery grounds is key to understanding their full life history and to conserving essential habitat.

Early juvenile stages of rockfishes have been found to recruit in higher densities to structured habitats than in habitats without structure (Love et al., 1991; Rooper et al., 2007; Love et al., 2012), indicating that structured habitats are used as nurseries by rockfish in early life history stages. It has been observed that, in shallow coral reef habitats (depths: $<50 \mathrm{~m}$ ), larval fish migrate vertically downward into corals to avoid currents, movements that can prevent larvae from being carried away and, therefore, can help them remain in coral habitat (Paris and Cowen, 2004). Redfish larvae (Sebastes spp.) have been captured in close association with sea pens (order Pennatulacea) by using bottom-trawl gear (Baillon et al., 2012). Sea pens may serve a similar purpose as corals in shallow-water habitats, by retaining larvae in nursery habitats with seafloor structure. These observations have led to the hypothesis that rockfish in early life history stages recruit to and are retained in deep-sea coral habitats that are beneficial to their 
survival. Several factors have led to difficulty in exploring this hypothesis. First, trawling for samples both destroys the habitat (Hourigan, 2009; Clark et al., 2016) and integrates catches over large distances, making fine-scale associations difficult to determine. Second, identification of the early life stages of rockfishes is difficult prior to development of distinguishing characteristics (Matarese et al., 1989; Johansson et al., 2018).

We developed a plankton pump to sample zooplankton and larval fish in deepwater coral habitat in Alaska (Wilborn et al., 2020). The plankton pump provides a non-destructive method of sampling that can provide fine-scale information on habitat associations. The aim of this study was to explore the potential role of deepsea coral habitat in the early life history of rockfishes in the North Pacific Ocean without damaging the habitat. Genetic techniques solved the second issue of species identification. The objectives of this note are to report the first known instance of a single larval rockfish captured directly from deep-sea coral habitat and to discuss supplementary evidence from larval rockfish captured in association with deep-sea corals during bottom-trawl surveys in the Gulf of Alaska.

\section{Materials and methods}

The method used to capture zooplankton and larval fish from coral and sponge habitats in the Gulf of Alaska is described in Wilborn et al. (2020). In brief, the plankton pump is an autonomous sampler that was deployed from a contracted research vessel at depths of 80-105 m. We deployed the pump 8 times, in areas of known coral and sponge habitat, as well as in areas without coral and sponge habitat (5 and 3 deployments, respectively). It was programmed to sample the seafloor plankton by drawing water through a 333- $\mu$ m-mesh zooplankton net. Sampling began after the pump reached the seafloor and ended after $15 \mathrm{~min}$, with an automated door closure preventing contamination of the sample during retrieval. The mean volume of water filtered per deployment was $6.32 \mathrm{~m}^{3}$ (standard deviation 2.46). Prior to retrieval of the plankton pump, a series of photographs of the seafloor were taken by a camera mounted on the pump to document the surrounding habitat. The 8 samples were collected in the western Gulf of Alaska between the Shumagin Islands $\left(\sim 158^{\circ} \mathrm{W}\right)$ and Samalga Pass $\left(\sim 170^{\circ} \mathrm{W}\right)$ in 2017 (further details on this sampling and the organisms captured can be found in Wilborn et al., 2020). All samples collected from the plankton pump were individually extracted and preserved in plastic containers with a $95 \%$ solution of ethanol and glycerol for further analysis in the laboratory.

To genetically identify the larval rockfish captured in the plankton pump, a 750-base-pair (bp) region of the mitochondrial cytochrome $b$ gene was amplified to identify the rockfish to species. This method has been used successfully to discriminate among known species of rockfish (RochaOlivares et al., 1999). For each sampled larva, DNA was extracted from the caudal fin by using a QIAamp ${ }^{1}$ DNA micro kit (Qiagen Inc., Hilden, Germany) and eluted in $25 \mu \mathrm{L}$ of buffer. The mitochondrial DNA fragment of the cytochrome $b$ gene was amplified through a polymerase chain reaction cocktail by using primers GluDG (5'TGA CTT GAA RAA CCA YCG TTG 3') and CB3R (5' ATA TCA TTC TGG CTT AAT GTG 3') as described in Rocha-Olivares et al. (1999). Thermalcycling conditions were $90^{\circ} \mathrm{C}$ for $2 \mathrm{~min}$, followed by 36 cycles of $94^{\circ} \mathrm{C}$ for $50 \mathrm{~s}, 51^{\circ} \mathrm{C}$ for $50 \mathrm{~s}$, and $72^{\circ} \mathrm{C}$ for $50 \mathrm{~s}$. Polymerase chain reaction fragments were visualized with E-Gel EX Agarose gels (1\%; Thermo Fisher Scientific, Waltham, MA). Polymerase chain reaction products were cleaned and sequenced in forward and reverse directions at Molecular Cloning Laboratories in San Francisco, California. The resulting data were assembled in Sequencher, vers. 5.0 (Gene Codes Corp.,Ann Arbor, MI). High-quality forward and reverse sequences (with quality scores $>40$ ) were aligned to produce a 655-bp fragment of the mitochondrial cytochrome $b$ region in Sequencher. Consensus sequences were aligned in the sequence alignment editor in BioEdit (vers. 7.2; Hall, 1999) to highlight differences, and trimmed sequences were assigned GenBank accession numbers (Table 1) (GenBank, available from website).

In addition to analyzing DNA from the single unknown rockfish larva, for comparison, we sequenced DNA from adults of 4 species of rockfish known to occur in the region where the larva was collected (Table 1). The new sequences of DNA from these adults were cataloged in the University of Washington Fish Collection (available from website). The 4 species are Pacific ocean perch (Sebastes alutus) (voucher no. UW151031), dusky rockfish (S. ciliatus) (UW155786), northern rockfish (S. polyspinis) (UW155787 and UW189442), and light dusky rockfish (S. variabilis) (UW45510). We also compared the DNA from the larva to DNA from another available specimen of northern rockfish (UW113251) for which DNA had been sequenced during an unrelated study in the eastern North Pacific Ocean (at $52^{\circ} 34^{\prime} \mathrm{N}, 170^{\circ} 41^{\prime} \mathrm{W}$ ) in 2004. We expected the unknown rockfish larva to be identified either through sequences from the 6 samples on hand or through sequences available in open-access repositories of genetic data (e.g., GenBank).

Subsequent to the capture of the northern rockfish larva in 2017, a reexamination of corals collected during the bottom-trawl survey conducted by the NOAA Alaska Fisheries Science Center in the Gulf of Alaska in 2017 was undertaken. These coral specimens were collected as part of routine efforts to collect genetic information on corals and sponges in the Gulf of Alaska. Additional rockfish larvae were found lodged in specimens of 2 species of coral (a Plumarella superba and a Callogorgia compressa; Fig. 1). The larvae and corals were collected on 30 May 2017 from the haul of a bottom-trawl tow conducted at a depth of $136 \mathrm{~m}$ in the Gulf of Alaska $\left(52^{\circ} 41^{\prime} \mathrm{N}, 169^{\circ} 32^{\prime} \mathrm{W}\right)$. The DNA from 5 individuals associated with Callogorgia compressa and from 6 individuals associated with

\footnotetext{
${ }^{1}$ Mention of trade names or commercial companies is for identification purposes only and does not imply endorsement by the National Marine Fisheries Service, NOAA.
} 


\section{Table 1}

GenBank accession numbers, corresponding University of Washington Fish Collection database (UW) voucher numbers, and species names of individual rockfish (Sebastes spp.) that had their DNA sequenced for comparison to DNA from the larval rockfish collected as part of this study in 2017 in the Gulf of Alaska. GenBank accession numbers for an additional 11 larvae were OM141006-OM141016.

\begin{tabular}{llll}
\hline UW voucher no. & Species identified & Species common name & GenBank no. \\
\hline UW155787 & S. polyspinis & Northern rockfish & MH686385 \\
UW45510 & S. variabilis & Light dusky rockfish & MH686386 \\
UW151031 & S. alutus & Pacific ocean perch & MH686387 \\
UW155786 & S. ciliatus & Dusky rockfish & MH686388 \\
UW189442 & S. polyspinis & Northern rockfish & MH686389
\end{tabular}

Plumarella superba were sequenced by using the same methods described in a previous paragraph. Species identification was performed by comparing the resulting sequences to sequences from this study (Table 1) or to sequences found in GenBank by using the Basic Local Alignment Search Tool (BLAST, available from website) (Johnson et al., 2008) if an exact match did not exist among sequences provided in Table 1.

\section{Results and discussion}

A sample collected with the plankton pump on 8 June 2017 in the Gulf of Alaska south of Unimak Island, Alaska $\left(54^{\circ} 10^{\prime} \mathrm{N}, 162^{\circ} 14^{\prime} \mathrm{W}\right)$, at a depth of $93 \mathrm{~m}$ in coral habitat included a single larval rockfish (Fig. 1). No larvae were captured in samples taken during the other 7 deployments of the plankton pump. The habitat where the larval rockfish

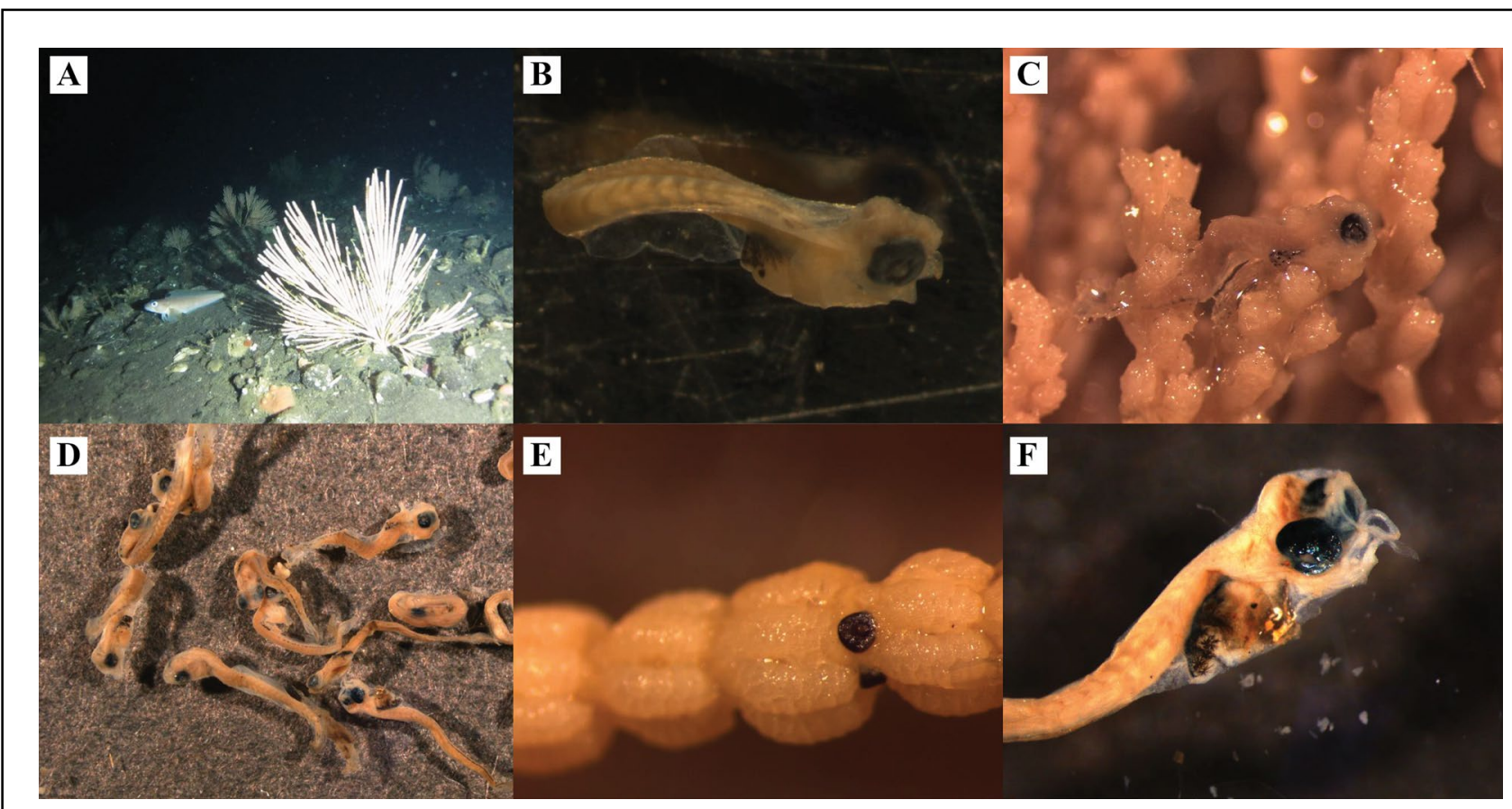

Figure 1

Images of deepwater coral habitat and rockfish larvae (Sebastes spp.) associated with collections made with a plankton pump during this study or made during the bottom-trawl survey conducted by the NOAA Alaska Fisheries Science Center (AFSC) in the Gulf of Alaska in 2017: (A) deepwater coral habitat where the larval northern rockfish was collected with the plankton pump, (B) the northern rockfish larva collected in the plankton pump, (C) a larval rockfish with a coral of Plumarella superba from the collection of specimens captured during the AFSC bottom-trawl survey, (D) rockfish larvae collected from corals sampled during the AFSC bottom-trawl survey, (E) a larval rockfish nestled in a coral of Callogorgia compressa collected during the AFSC bottom-trawl survey, and (F) a larval rockfish retrieved from the collection of the AFSC bottom-trawl survey. 
was captured was predominantly soft sediment but had some cobble and boulder-sized rocks intermixed throughout. Corals (especially Callogorgia sp.) were abundant at the deployment location where the larva was captured and on the surrounding seafloor (Fig. 1). The specimen was $5.53 \mathrm{~mm}$ in length and weighed $0.2 \mathrm{~g}$. The size of extrusion for northern rockfish is not known but is expected to be less than $6.1 \mathrm{~mm}$ (Matarese et al., 1989), and in general the size of extrusion for most rockfish species is $5-7 \mathrm{~mm}$ (Love et al., 2002). The specimen was visually identified as a rockfish (Sebastes sp.) and was considered to have recently extruded because of its small size.

The larval specimen in question differed by $1 \mathrm{bp}$ at position 246 from the vouchered northern rockfish specimen (UW155787) but was an exact match to the our newly sequenced northern rockfish specimen (UW189442) and to 2 specimens of northern rockfish in GenBank: catalog no. EF446443.1 (voucher no. UW113251) and catalog no. DQ678512.1 (voucher no. SQFSC121-69 (Hyde and Vetter, 2007). Therefore, we concluded that this larval fish was a northern rockfish.

For the additional 11 larvae associated with corals, all sequences associated with Plumarella superba and 4 of the 5 larvae associated with Callogorgia compressa matched the sequence for our recent specimen (UW189442) (Table 1) and were identified as northern rockfish. One individual associated with Callogorgia compressa matched the sequence for DQ678476.1 (SWFSC173-8) and was identified as a harlequin rockfish ( $S$. variegatus) (Hyde and Vetter, 2007). These 11 larvae were all found in corals, settled among polyps as shown in Figure 1. This observation is similar to that of Baillon et al. (2012), who also observed larvae of Atlantic redfish (Sebastes sp.) situated among polyps of pennatulaceans in trawl hauls. Baillon et al. (2012) observed the Atlantic redfish larvae in bottomtrawl hauls that also captured adult Atlantic redfish; therefore, the larvae may have been extruded in the net and swept into the pennatulacean polyps by the action of the trawl gear. During the bottom-trawl survey conducted in 2017 in the Gulf of Alaska, adult northern rockfish did occur in 1 of the 2 trawl hauls in which its larvae were also captured, but adult harlequin rockfish did not occur in the bottom-trawl haul in which the larval harlequin rockfish was found, indicating that the occurrence of these larvae on corals was not necessarily a consequence of the capture process inducing extrusion of rockfish larvae within the trawl net.

The capture of free-swimming northern rockfish larvae by using a plankton pump is the first in situ record of a rockfish larva confirmed to have been captured from within deepwater coral habitat. Little is known of the early life history of Alaska rockfishes or of northern rockfish in particular, but species of Sebastes generally have an extensive pelagic larval phase of up to 1 year in duration and a limited lifetime dispersal indicated by genetic studies (Miller and Shanks, 2004; Hyde and Vetter, 2007; Gharrett et al., 2012; Kamin et al., 2014). These 2 characteristics of their life history appear to be somewhat in conflict, in that species with the potential for long-distance dispersal would not be expected to have restricted geographic dissemination. However, results of a study of 11 microsatellite loci of northern rockfish captured along the range of this species in the Bering Sea and Aleutian Islands of Alaska reveal a significant isolation-by-distance relationship, indicating limited lifetime dispersal of between approximately 12 and $120 \mathrm{~km}$ for this species (Gharrett et al., 2012). Reduced currents downstream of coral habitat (and potentially other highly structured habitats) may provide a process for larval rockfish to be retained near where they were spawned, creating an important mechanistic link between the known genetic structure of northern rockfish and restricted dispersal.

This unique observation of a larval northern rockfish in deep-sea coral habitat improves our knowledge of the early life history of this commercially important species and may provide insight into a potential mechanism for larval retention for a taxonomic group that has a high degree of population structure and limited lifetime dispersal. The result also highlights the further importance of deepwater coral habitat as essential habitat for rockfishes.

\section{Acknowledgments}

The University of Washington Fish Collection archived most of the material examined for this study, and we appreciate the support of its curator (L. Tornabene) and collections manager (K. Maslenikov).

\section{Literature cited}

Baillon, S., J.-F. Hamel, V. E. Wareham, and A. Mercier. 2012. Deep cold-water corals as nurseries for fish larvae. Front. Ecol. Environ. 10:351-356. Crossref

Buhl-Mortensen, L., and P. B. Mortensen.

2004. Crustaceans associated with the deep-water gorgonian corals Paragorgia arborea (L., 1758) and Primnoa resedaeformis (Gunn., 1763). J. Nat. Hist. 38:1233-1247. Crossref

Clark, M. R., F. Althaus, T. A. Schlacher, A. Williams, D. A. Bowden, and A. A. Rowden.

2016. The impacts of deep-sea fisheries on benthic communities: a review. ICES J. Mar. Sci. 73(suppl_1):i51-i69. Crossref

Gharrett, A. J., R. J. Riley, and P. D. Spencer.

2012. Genetic analysis reveals restricted dispersal of northern rockfish along the continental margin of the Bering Sea and Aleutian Islands. Trans. Am. Fish. Soc. 141:370-382. Crossref

Hall, T. A.

1999. BioEdit: a user-friendly biological sequence alignment editor and analysis program for Windows 95/98/NT. Nucleic Acids Symp. Ser. 41:95-98.

Hourigan, T. F.

2009. Managing fishery impacts on deep-water coral ecosystems of the USA: emerging best practices. Mar. Ecol. Prog. Ser. 397:333-340. Crossref

Hyde, J. R., and R. D. Vetter.

2007. The origin, evolution, and diversification of rockfishes of the genus Sebastes (Cuvier). Mol. Phylogenet. Evol. 44:790-811. Crossref 
Johansson, M. L., M. N. C. Litz, R. D. Brodeur, T. A. Britt, C. A. Vanegas, J. R. Hyde, and M. A. Banks.

2018. Seasonal distribution of late larval and juvenile rockfish (Sebastes spp.) and associated environmental conditions off Oregon and Washington: new insights based on genetics. Fish. Bull. 116:266-280. Crossref

Johnson, M., I. Zaretskaya, Y. Raytselis, Y. Merezhuk, S. McGinnis, and T. L. Madden.

2008. NCBI BLAST: a better web interface. Nucleic Acids Res. 36(suppl_2):W5-W9. Crossref

Kamin, L. M., K. J. Palof, J. Heifetz, and A. J. Gharrett.

2014. Interannual and spatial variation in the population genetic composition of young-of-the-year Pacific ocean perch (Sebastes alutus) in the Gulf of Alaska. Fish. Oceanogr. 23:1-17. Crossref

Love, M. S., M. H. Carr, and L. J. Haldorson.

1991. The ecology of substrate-associated juveniles of the genus Sebastes. Environ. Biol. Fishes 30:225-243. Crossref

Love, M. S., M. Yoklavich, and L. Thorsteinson.

2002. The rockfishes of the northeast Pacific, 414 p. Univ. Calif. Press, Berkeley, CA.

Love, M. S., M. Nishimoto, S. Clark, and D. M. Schroeder. 2012. Recruitment of young-of-the-year fishes to natural and artificial offshore structure within central and southern California waters, 2008-2010. Bull. Mar. Sci. 88:863-882. Crossref

Matarese, A. C., A. W. Kendall Jr., D. M. Blood, and B. M. Vinter. 1989. Laboratory guide to early life stages of Northeast Pacific fishes. NOAA Tech. Rep. NMFS 80, 652 p.
Miller, J. A., and A. L. Shanks.

2004. Evidence for limited larval dispersal in black rockfish (Sebastes melanops): implications for population structure and marine-reserve design. Can. J. Fish. Aquat. Sci. 61:1723-1735. Crossref

Paris, C. B., and R. K. Cowen.

2004. Direct evidence of a biophysical retention mechanism for coral reef fish larvae. Limnol. Oceanogr. 49:1964-1979. Crossref

Rocha-Olivares, A., C. A. Kimbrell, B. J. Eitner, and R. D. Vetter. 1999. Evolution of a mitochondrial cytochrome $b$ gene sequence in the species-rich genus Sebastes (Teleostei, Scorpaenidae) and its utility in testing the monophyly of the subgenus Sebastomus. Mol. Phylogenet. Evol. 11:426-440. Crossref

Rooper, C. N., J. L. Boldt, and M. Zimmermann.

2007. An assessment of juvenile Pacific Ocean perch (Sebastes alutus) habitat use in a deepwater nursery. Estuar. Coast. Shelf Sci. 75:371-380. Crossref

Watling, L., S. C. France, E. Pante, and A. Simpson.

2011. Biology of deep-water octocorals. Adv. Mar. Biol. 60:41-122. Crossref

Wilborn, R. E., C. N. Rooper, P. Goddard, K. Williams, and R. Towler. 2020. A novel design for sampling benthic zooplankton communities in disparate Gulf of Alaska habitats using an autonomous deep-water plankton pump. J. Plankton Res. 42:457-466. Crossref 